\title{
SISTEM INFORMASI ADMINISTRASI AKADEMIK PADA BAAK STMIK WIDYA CIPTA DHARMA SAMARINDA BERBASIS WEB
}

\author{
Ekatiwati Yulsilviana $^{1)}$, Amelia Yusnita ${ }^{2)}$, Muhammad Ridhuan. S $^{3)}$ \\ ${ }^{1}$ Manajemen Informatika, STMIK Widya Cipta Dharma \\ ${ }^{2,3}$ Sistem Informasi, STMIK Widya Cipta Dharma \\ ${ }_{1,2,3}$ Jl. Prof. M. Yamin No. 25, Samarinda, 75123 \\ E-mail : ekawicida@gmail.com ${ }^{1)}$, lia_amelia@yahoo.co.id ${ }^{2)}$,berinspirasilah@gmail.com ${ }^{3)}$
}

\begin{abstract}
ABSTRAK
Penelitian dilakukan untuk dapat membuat sebuah Sistem Informasi Administrasi Akademik Pada BAAK STMIK Widya Cipta Dharma Samarinda Berbasis Web yang nantinya jika penelitian ini berhasil, sistem yang dibangun akan mempermudah BAAK STMIK Widya Cipta Dharma Samarinda dalam menjalankan tugasnya.

Penelitian ini dilakukan di BAAK STMIK Widya Cipta Dharma Samarinda, metode pengumpulan data yang digunakan adalah melalui studi pustaka yaitu mempelajari contoh sistem yang akan dibuat, pengamatan secara langsung melalui wawancara yaitu bertanya tentang proses maupun konten yang akan ditampilkan, dan melalui dokumentasi yaitu menganalisis atau mempelajari dokumen-dokumen yang berhubungan dengan sistem yang akan dibangun.

Dalam penelitian ini metode pengembangan sistem yang digunakan yaitu prototype. Alat bantu yang digunakan dalam pengembangan sistem antara lain Flowchart dan Site Map ( Peta Situs ). Serta menggunakan software XAMPP untuk menjalankan website dan Notepad++ sebagai editor.
\end{abstract}

Kata Kunci: sistem informasi administrasi akademik

\section{PENDAHULUAN}

Sistem informasi pada dunia pendidikan berperan untuk menjadikan proses belajar mengajar menjadi lebih kreatif dan kompetitif, selain itu dalam pendidikan memanfaatkan kemajuan teknologi yang ada untuk menyampaikan informasi dapat lebih efektif dan mudah tersampaikan kepada yang dituju, yakni mahasiswa dan civitas akademika. Terutama untuk lembaga pendidikan yang bertujuan menciptakan tenaga ahli dibidang information and technology, sewajarnya mampu untuk memanfaatkan dan menerapkan sistem informasi yang lebih baik agar informasi lebih mudah tersampaikan.

Bagian administrasi akademik kemahasiswaan atau BAAK di sekolah tinggi manajemen informatika dan komputer Widya Cipta Dharma Samarinda merupakan salah satu bagian penting untuk membantu proses perkuliahan seperti pembuatan transkip nilai, pengurusan beasiswa, pengajuan surat penelitian dan lain lain. Karena banyaknya jenis pelayanan pada bagian BAAK, menjadikan BAAK salah satu bagian yang cukup sibuk menghadapi mahasiswa yang perlu mengurus keperluan akademik juga sering terjadinya penumpukan pada loket, sehingga dirasa perlu adanya sebuah website untuk membantu menyelesaikan tugas BAAK.

\section{RUANG LINGKUP PENELITIAN}

Permasalahan difokuskan pada:

1. Sistem yang dibangun mampu mempermudah dalam penyampaian informasi yang diberikan BAAK untuk membantu proses perkuliahan dan keperluan akademik para mahasiswa di STMIK Widya Cipta Dharma Samarinda.

2. Pengelompokan user yang terlibat dalam sistem terbagi menjadi:

1) Pengunjung dan mahasiswa (Front End)

2) Staf BAAK (Back End)

3) Kepala BAAK (Back End).

3. Adapun tujuan penelitian ini adalah:

1) Mempermudah Bagian administrasi akademik kemahasiswaan atau BAAK STMIK Widya Cipta Dharma Samarinda dalam menjalankan tugasnya.

2) Menerapkan ilmu yang telah dipelajari tentang website serta menerapkan ilmu dibidang teknologi.

\section{BAHAN DAN METODE}

Teori-teori yang dijadikan sebagai pegangan dalam membangun sistem dan metode pengembangan sistem yang digunakan yaitu:

\subsection{Penjelasan Bahan}

1. Menurut Mulyanto (2009), mendefinisikan sistem informasi sebagai suatu komponen yang terdiri dari manusia, teknologi informasi, dan prosedur kerja yang memproses, menyimpan, menganalisis, dan menyebarkan informasi untuk mencapai suatu tujuan.

2. Menurut Anonim (2014), BAAK atau Bagian Administrasi Akademik dan Kemahasiswaan adalah unsur pimpinan yang membantu Ketua dibidang administrasi akademik dan kemahasiswaan yang 
berada di bawah dan bertanggung jawab langsung kepada Ketua dan sehari-hari di bawah pembinaanya dilakukan oleh Wakil Ketua I Bidang Akademik, wakil ketua III Bidang Kemahasiswaan.

3. Menururt Shalahuddin (2010), Website adalah informasi di dalam world wide web yang disimpan dalam file yang berbeda-beda sebagai halaman web. Homepage merupakan halaman awal dari sebuah situs web.

\subsection{Metode Prototype Evolusioner}

Menurut McLeod (2008), Prototype Evolusioner merupakan prototype yang terus menerus disempurnakan sampai memiliki seluruh fungsionalitas yang dibutuhkan pengguna dari sistem yang baru. Prototype ini kemudian dilanjutkan produksi. Jadi, satu Prototype Evolusioner akan menjadi sistem aktual.

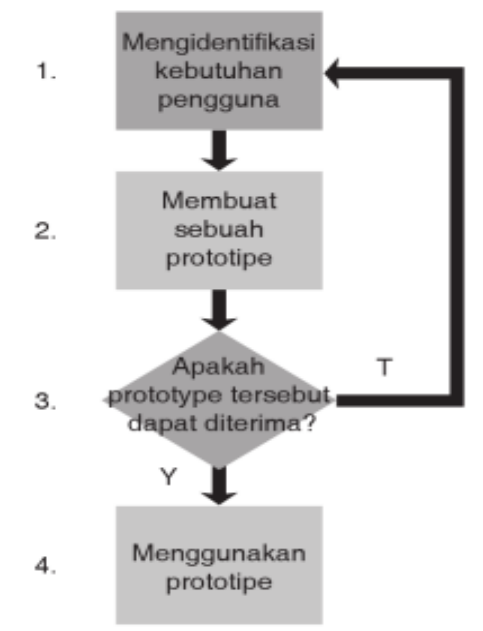

\section{Gambar 1. Pembuatan Prototype Evolusioner}

Penjelasan dari tahapan dalam prototype evolusioner ini adalah:

1. Mengidentifikasi kebutuhan pengguna. Pengembang mewawancarai pengguna untuk mendapatkan ide mengenai apa yang diminta dari sistem.

2. Membuat sebuah prototype. Pengembang mempergunakan satu alat prototyping atau lebih untuk membuat prototype. Contoh dari alat-alat prototyping adalah generator aplikasi terintegrasi dan toolkit prototyping.

3. Menentukan apakah prototype dapat diterima. Pengembang akan mendemonstrasikan prototype kepada pengguna untuk mengetahui apakah telah memberikan hasil yang memuaskan. Jika ya, langkah 4 diambil. Jika tidak, prototype direvisi dengan mengulang kembali langkah 1, 2, dan 3 dengan pemahaman yang lebih baik mengenaik kebutuhan pengguna.

4. Menggunakan prototype. Prototype menjadi sistem produksi

\section{RANCANGAN SISTEM/APLIKASI}

Untuk mempermudah melihat dan mempelajari strukrur website yang dibangun maka dilakukan pembuatan site map website dan flowchart website untuk detail dari proses pengajuan, desain antar muka sebagai bentuk dasar website, dan struktur database untuk menyimpan data.

\subsection{Site Map}

Pada bagian ini terdiri dari 3 buah site map yang digunakan untuk membantu memahami sistem yang dibuat, yaitu untuk halaman pengunjung dan mahasiswa, staf BAAK, dan juga untuk kepala BAAK.

1. Site Map Halaman Pengunjung dan Mahasiswa

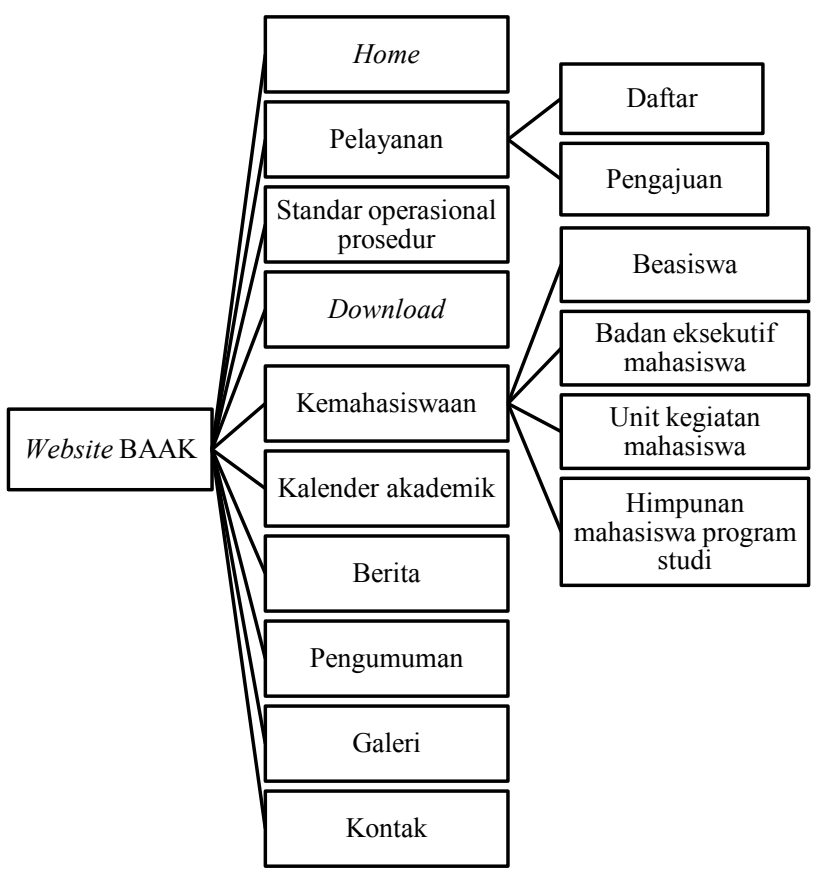

\section{Gambar 2. Site Map Halaman Pengunjung dan Mahasiswa}

Pada gambar 2, merupakan site map untuk halaman pengunjung dan mahasiswa, saat pengunjung atau mahasiswa menuju alamat website, maka akan diarahkan ke halaman Home, pada halaman tersebut pengunjung atau mahasiswa dapat melihat slide show, berita dan pengumuman terbaru, pada halaman pelayanan dapat melakukan pendaftaran akun jika tidak memiliki akun atau membuat pengajuan, pada halaman lainnya dapat melihat standar oprasional prosedur, mendownload fail yang diperlukan, melihat info kemahasiswaan, melihat kalender akademik, melihat daftar berita, melihat daftar pengumuman, melihat foto di galeri, bertanya pada menu kontak 


\section{Site Map Halaman Staf BAAK}

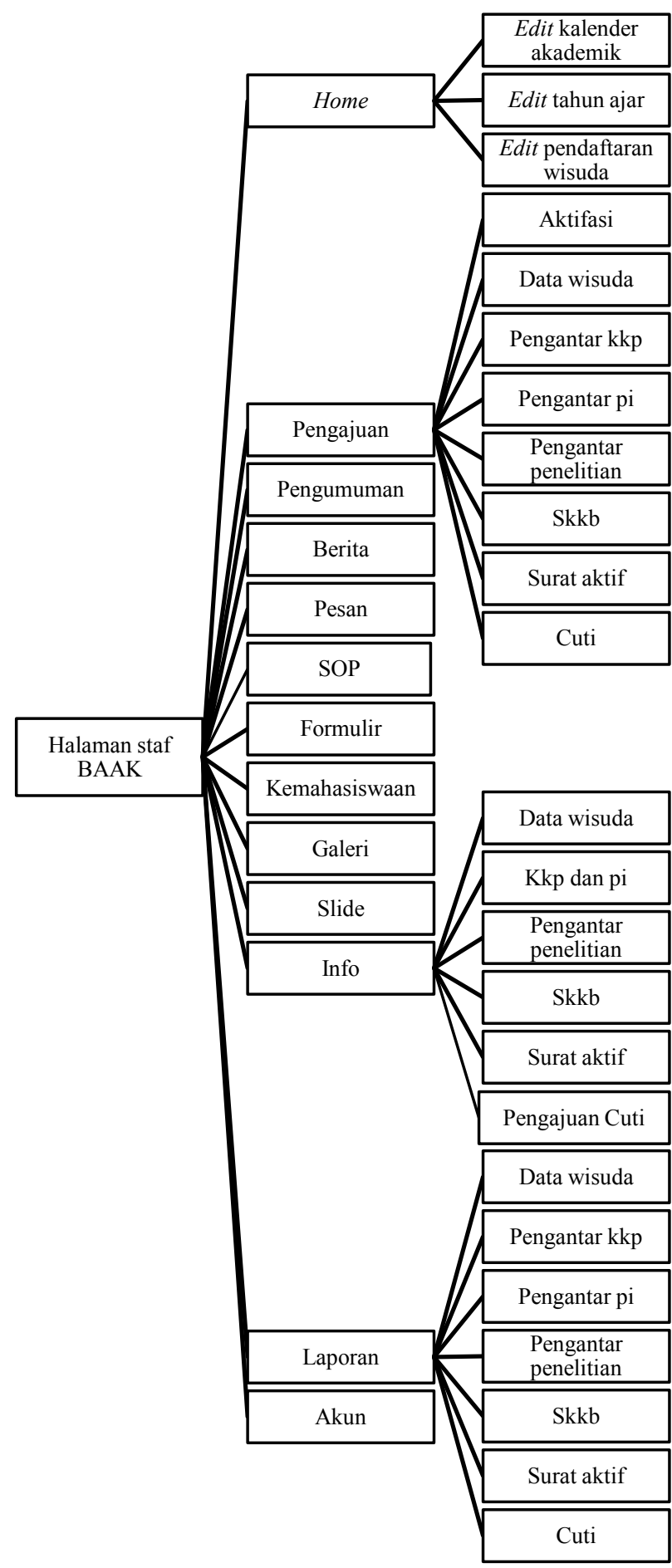

Gambar 3. Site Map Halaman Staf BAAK

Gambar 3, merupakan site map untuk halaman staf BAAK setelah melalui halaman login yang akan diarahkan kehalaman home, pada halaman home staf BAAK dapat merubah kalender akademik, merubah tanggal pendaftaran wisuda dan merubah tahun ajaran. Pada menu pengajuan dapat memproses pengajuan dari mahasiswa. Pada menu yang lain terdapat fitur untuk menambah, merubah dan menghapus yaitu pada menu pengumuman dan berita. Pada bagian menu pesan dapat membalas pesan yang masuk dan dikirim melalui email. Selain itu ada juga fitur menambah, merubah dan menghapus untuk standar oprasional prosedur (SOP), formulir, kemahasiswaan dan galeri. Merubah tampilan gambar pada menu slide untuk slide show dihalaman pengunjung. Pada bagian menu info dapat merubah informasi pada halaman pengunjung. Pada menu laporan menampilkan laporan untuk pengajuan. Pada menu akun terdapat fitur untuk merubah password dan nama untuk akun yang dipakai, mereset password mahasiswa juga mengaktifkan kembali akun mahasiswa yang akan aktif kuliah kembali.

3. Site Map Halaman Kepala BAAK

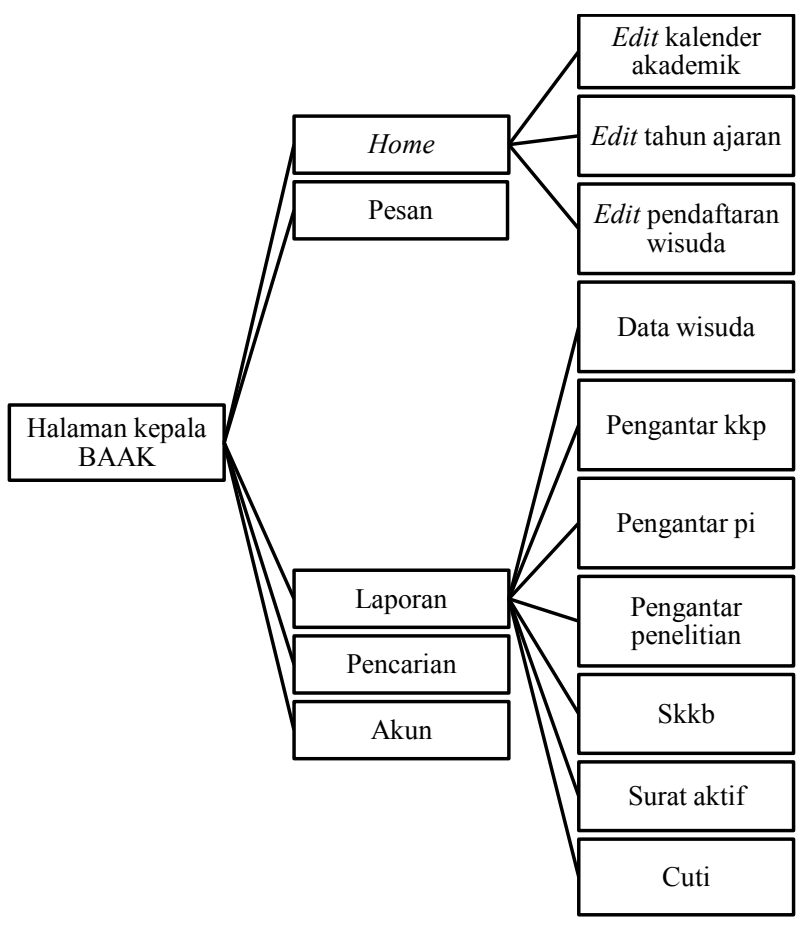

Gambar 4. Site Map Halaman Kepala BAAK

Gambar 4, merupakan site map untuk halaman kepala BAAK setelah melalui halaman login yang akan diarahkan kehalaman home, pada halaman home pimpinan dapat merubah kalender akademik, merubah tanggal pendaftaran wisuda dan merubah tahun ajaran. Pada bagian menu pesan dapat membalas pesan yang masuk dan dikirim melalui email. Pada menu laporan menampilkan laporan untuk pengajuan. Pada menu pencarian berguna untuk melihat histori pengajuan mahasiswa secara lengkap di catatan pengajuan website. Pada menu akun terdapat fitur untuk merubah nama dan password akun yang dipakai, juga menambah akun baru untuk staf BAAK dan merubah status serta password akun .

\subsection{Flowchart}

Pada bagian flowchart terdapat 16 flowchart yang dibuat, namun akan ditampilkan 2 flowchart yang mewakili proses yang sering dilakukan yaitu untuk pembuatan surat aktif oleh mahasiswa dan pencetakan surat aktif olah staf BAAK.

1. Flowchart Pembuatan Surat Aktif

Gambar 5, merupakan gambaran proses pengajuan surat aktif oleh mahasiswa, yang dimulai dengan memasukan alamat website di browser, setelah halaman 
website ditampilkan lalu mahasiswa memilih menu pelayanan, mengisi nim dan password pada kolom yang tersedia untuk login, setelah melakukan proses login pada halaman pengajuan memilih pembuatan surat aktif, lalu mengisi keterangan untuk apa surat aktif dibuat lalu menekan save untuk menyatakan telah selesai mengisi, website akan menampilkan informasi data telah tersimpan, maka data pengajuan masuk pada daftar proses, dan mahasiswa menunggu surat aktif jadi atau dicetak oleh BAAK.

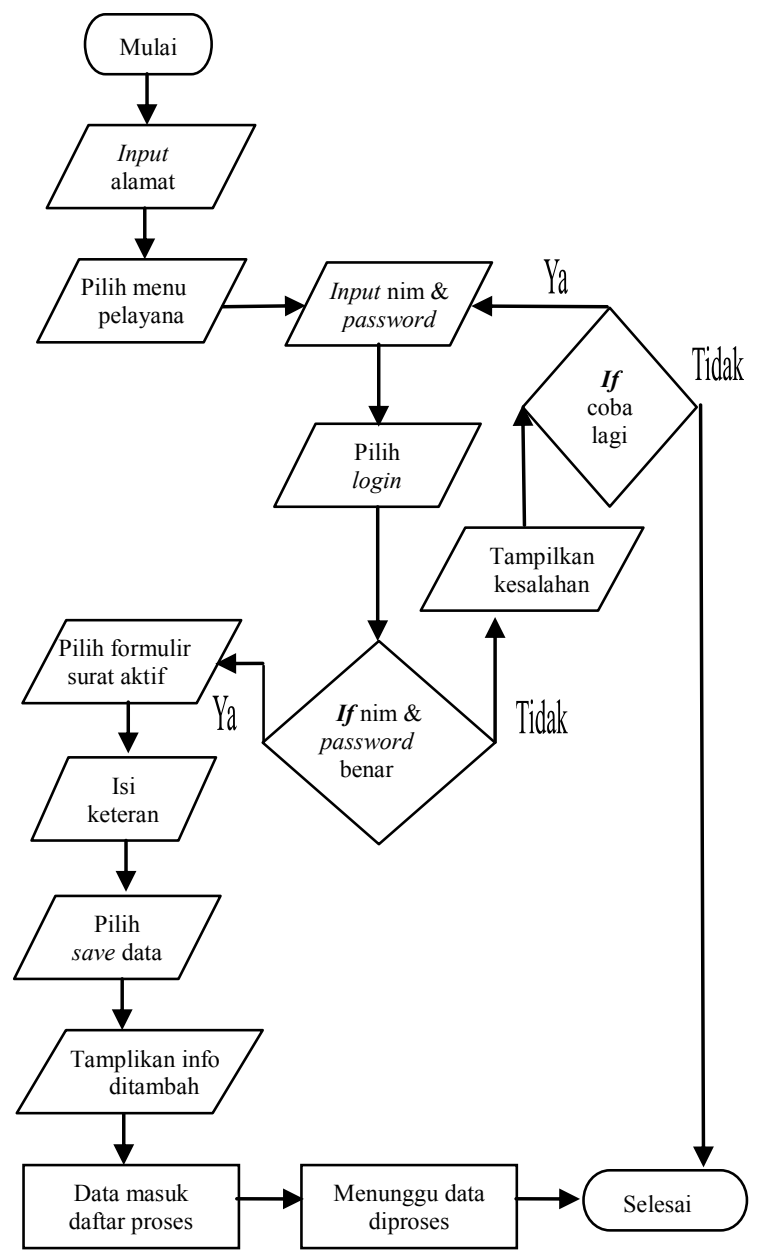

\section{Gambar 5. Flowchart Pembuatan Surat Aktif}

\section{Flowchart Pencetakan Surat Aktif}

Gambar 6, merupakan gambaran proses pencetakan surat aktif yang diajukan oleh mahasiswa, setelah staf BAAK melakukan proses login, staf BAAK memilih menu pengajuan dan sub menu surat aktif, pada daftar pengajuan surat aktif staf BAAK memeriksa status pembayaran BPP dan perwalian mahasiswa, jika mahasiswa yang diperiksa telah lunas dan melakukan perwalian maka surat aktif akan di print oleh staf BAAK dengan memilih terima lalu cetak, namun jika belum maka pengajuan di hapus dengan memilih x pada daftar pengajuan, proses akan berulang jika data masih ada.

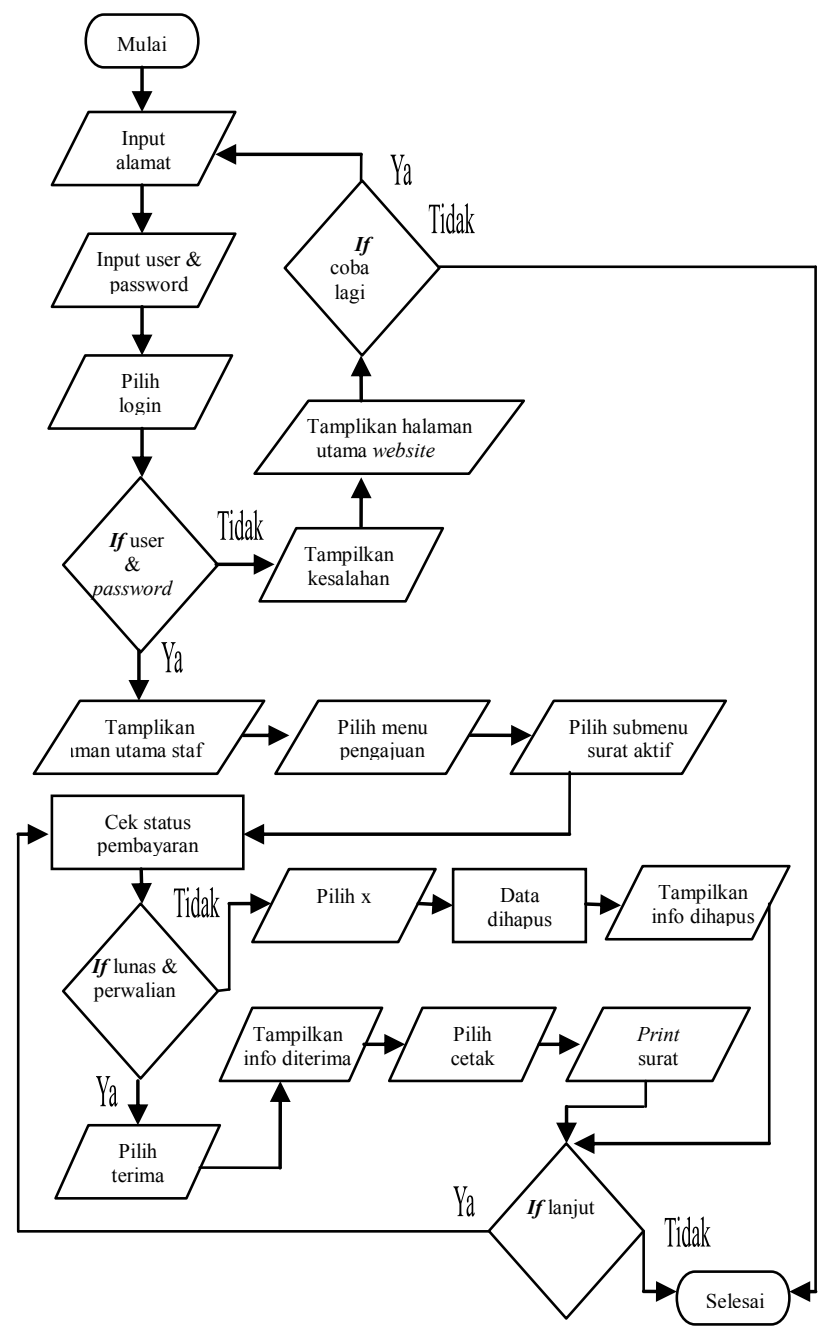

Gambar 6. Flowchart Pencetakan Surat Aktif

\subsection{Desain Antar Muka}

Pada bagian desain antar muka dibuat 16 desain untuk halaman pengunjung dan mahasiswa, 4 desain diantaranya yaitu desain untuk halaman home, pelayanan, akses menu pelayanan, dan pendaftaran.

1. Home

Gambar 7, merupakan desain untuk halaman home dari website, pada halaman ini nantinya menampilkan berita dan pengumuman yang terbaru serta slide gambar.

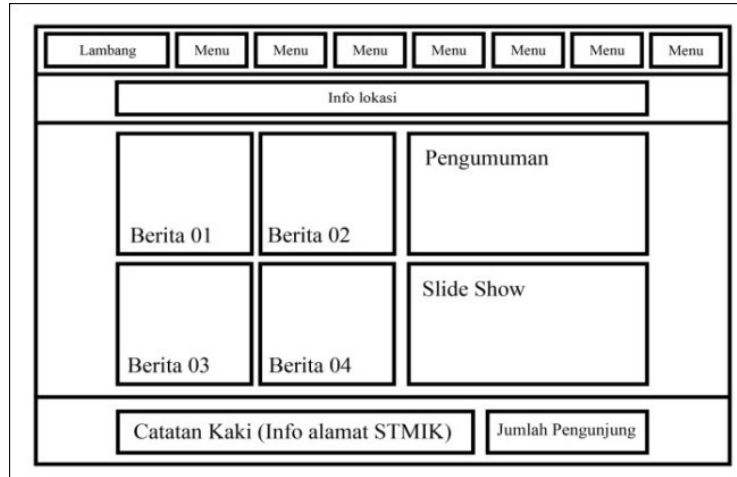

Gambar 7. Desain Halaman Home 


\section{Pelayanan}

Gambar 8, merupakan desain untuk halaman pelayanan dari BAAK, pada halaman ini menampilkan informasi dasar pengajuan, menu pelayanan yang bisa diakses setelah login, dan status dari akun yang dipakai.

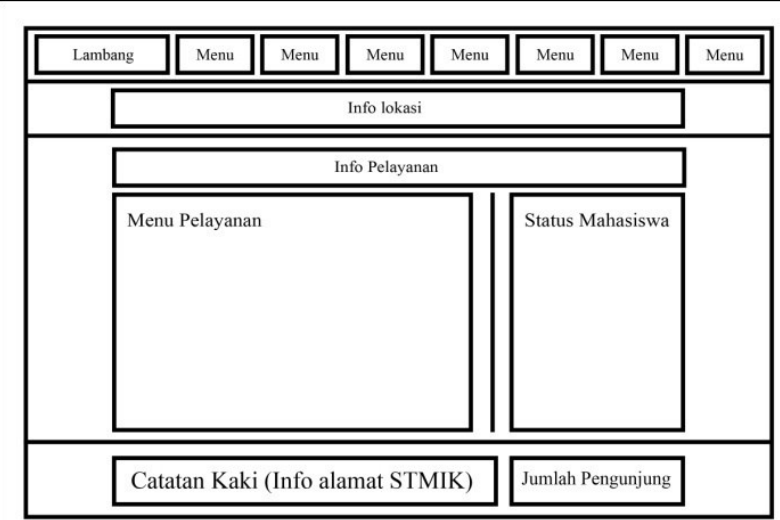

Gambar 8. Desain Halaman Pelayanan

\section{Akses Menu Pelayanan}

Gambar 9, merupakan desain untuk halaman akses pelayanan, pada halaman ini terdapat formulir pengajuan yang diakses, informasi pengajuan, dan status akun.

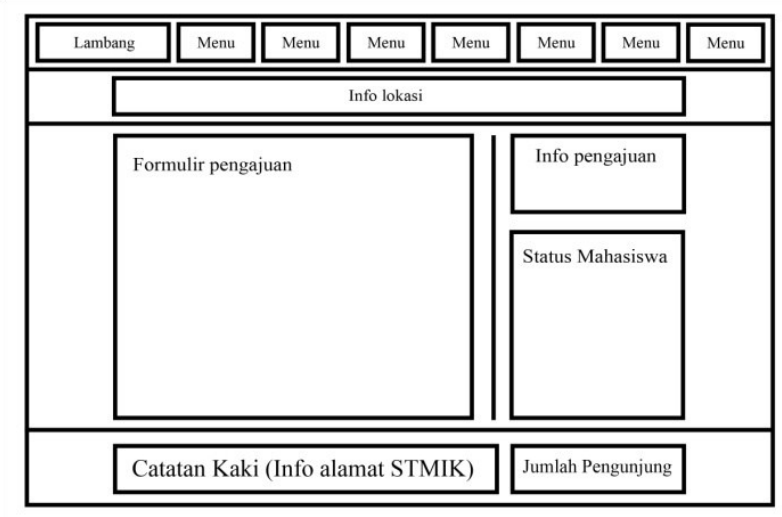

Gambar 9. Desain Menu Pelayanan

\section{Pendaftaran}

Gambar 10, merupakan desain untuk halaman pendaftaran akun mahasiswa, pada halaman ini menampilkan formulir yang akan diisi.

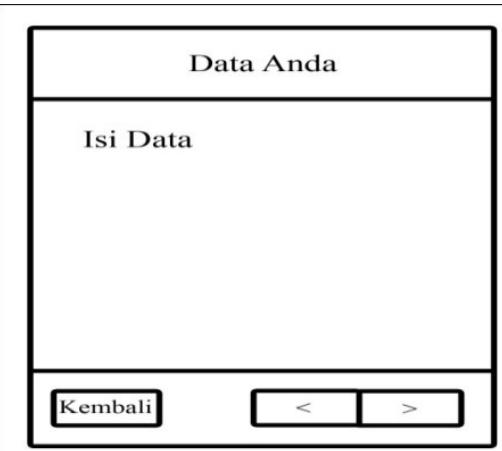

\subsection{Struktur Database}

Pada bagian struktur database dibuat 26 tabel yang digunakan untuk menyimpan data yang diperlukan, 4 tabel diantaranya yaitu tabel surat aktif, tabel akun mahasiswa, tabel berita, dan pengumuman.

1. Tabel Surat Aktif

Nama tabel : tbl aktif

Primary key : id aktif

Foreign key : id_mhs

Keterangan : merupakan tabel untuk menyimpan data mahasiswa yang melakukan pengajuan surat aktif.

Tabel 1. Tabel Surat Aktif

\begin{tabular}{|c|c|c|c|}
\hline No & field name & Type & Size \\
\hline 1 & id_aktif & int & 10 \\
\hline 2 & no & int & 10 \\
\hline 3 & id_mhs & int & 10 \\
\hline 4 & ket & varchar & 150 \\
\hline 5 & tglsa & datetime & \\
\hline 6 & tglsap & datetime & \\
\hline 7 & ssa & tinyint & 1 \\
\hline 8 & thaj & smallint & 5 \\
\hline
\end{tabular}

2. Tabel Akun Mahasiswa

Nama tabel : tbl mhs

Primary key : id_mhs

Keterangan : merupakan tabel untuk menyimpan data mahasiswa untuk melakukan pengajuan.

Tabel 2. Tabel Akun Mahasiswa

\begin{tabular}{|c|c|c|c|}
\hline No & Field Name & Type & Size \\
\hline 1 & id_mhs & int & 10 \\
\hline 2 & nim & mediumint & 7 \\
\hline 3 & aktn & tinyint & 2 \\
\hline 4 & koprodi & tinyint & 2 \\
\hline 5 & nama & varchar & 45 \\
\hline 6 & jk & char & 1 \\
\hline 7 & pass & varchar & 32 \\
\hline 8 & ja & tinyint & 1 \\
\hline 9 & alamat & varchar & 225 \\
\hline 10 & tempat & varchar & 35 \\
\hline 11 & tgl & date & \\
\hline 12 & nohp & bigint & 11 \\
\hline 13 & agama & tinyint & 1 \\
\hline 14 & foto & varchar & 11 \\
\hline 15 & sts & tinyint & 3 \\
\hline
\end{tabular}

3. Tabel Berita

Nama tabel : tbl_berita

Primary key : id_berita

Foreign key : id user

Keterangan : merupakan tabel untuk menyimpan berita dari BAAK. 


\section{Tabel 3. Tabel Berita}

\begin{tabular}{|c|c|c|c|}
\hline No & Field Name & Type & Size \\
\hline 1 & id_berita & int & 10 \\
\hline 2 & judul & varchar & 100 \\
\hline 3 & gambar & varchar & 150 \\
\hline 4 & ket & text & \\
\hline 5 & id_user & tinyint & 3 \\
\hline 6 & tgl & datetime & \\
\hline
\end{tabular}

4. Tabel Pengumuman

Nama tabel : tbl_pman

Primary key : id_pman

Foreign key : id_user

Keterangan : merupakan tabel untuk menyimpan data pengumuman yang diberikan oleh BAAK.

Tabel 4. Tabel Pengumuman

\begin{tabular}{|c|c|c|c|}
\hline No & Field Name & Type & Size \\
\hline 1 & id_pman & int & 10 \\
\hline 2 & judul & varchar & 100 \\
\hline 3 & isi & text & \\
\hline 4 & id_user & tinyint & 3 \\
\hline 5 & tgl & datetime & \\
\hline
\end{tabular}

\section{IMPLEMENTASI}

Hasil implementasi berdasarkan analisis dan perancangan adalah sebagai berikut:

1. Halaman Home Pengunjung dan Mahasiswa

Gambar 11, merupakan halaman home dari website, pada halaman ini menampilkan berita dan pengumuman yang terbaru serta slide gambar.

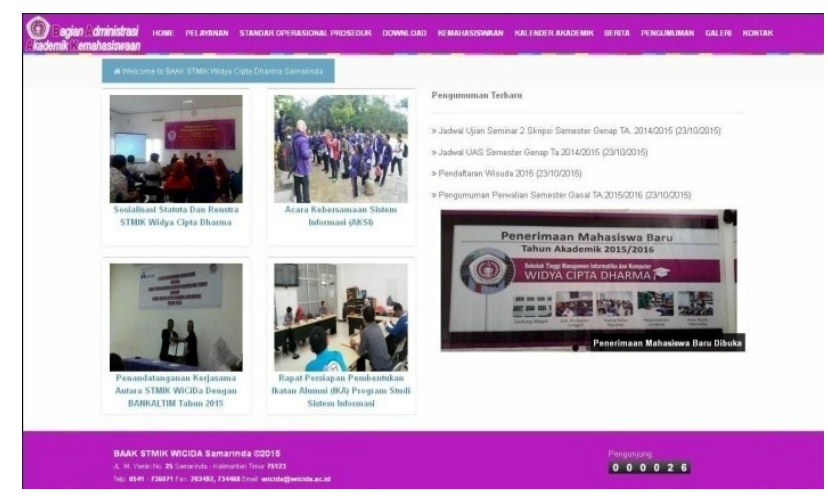

Gambar 11. Halaman Home Pengunjung dan Mahasiswa

2. Halaman Pelayanan

Gambar 12, merupakan halaman pelayanan untuk mahasiswa, pada halaman ini menampilkan informasi dasar pengajuan, menu pengajuan yang bisa diakses setelah login yaitu pengisian data wisuda, pembuatan surat pengantar KKP, pembuatan surat pengantar penulisan ilmiah, pembuatan pengantar penelitian skripsi, surat keterangan berkelakuan baik, surat aktif, surat pengajuan cuti, dan fitur untuk melakukan login serta akses menuju halaman pendaftaran.

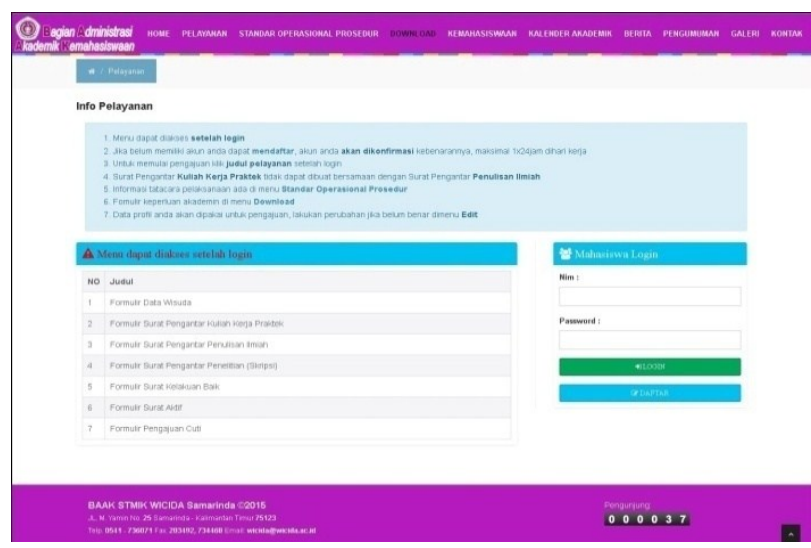

Gambar 12. Halaman Pelayanan

3. Halaman Pelayanan Surat Aktif

Gambar 13, merupakan halaman pelayanan untuk pembuatan surat aktif, pada halaman ini menampilkan formulir yang akan diisi mahasiswa, informasi pengajuan surat aktif, dan informasi akun mahasiswa.

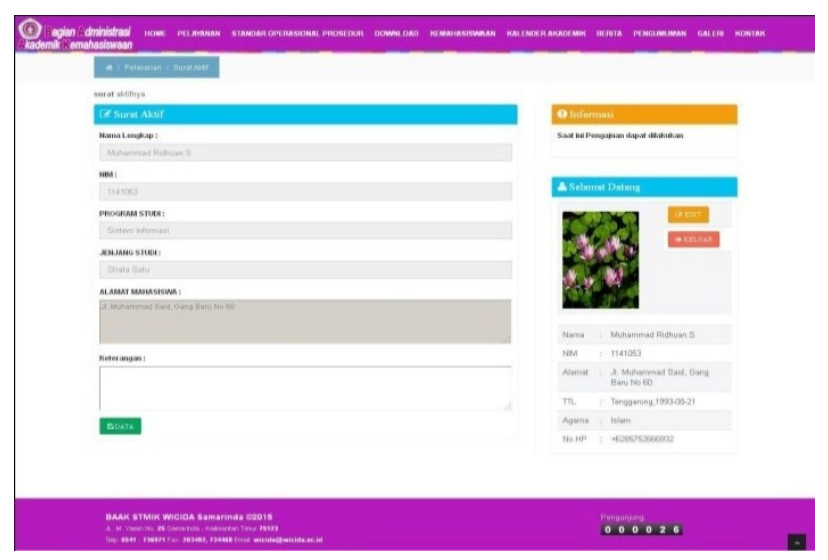

Gambar 13. Halaman Pelayanan Surat Aktif

4. Halaman Pendaftaran

Gambar 14, merupakan halaman pendaftaran akun untuk mahasiswa, pada halaman ini menampilkan formulir yang akan diisi.

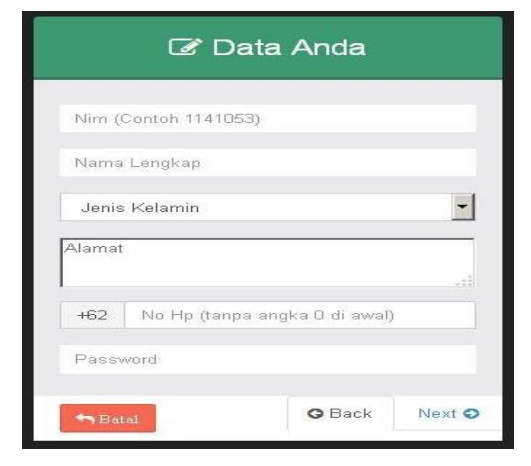

Gambar 14. Halaman Pendaftaran 


\section{Halaman Home Staf BAAK}

Gambar 15, merupakan halaman home untuk staf BAAK, terdapat pintasan untuk melihat pengajuan dengan jumlah yang memudahkan untuk proses pemeriksaan pengajuan dan pencetakan pengajuan, fitur merubah kalender akademin yang dipakai, tahun ajaran yang berlangsung, dan merubah tanggal pendaftaran untuk wisuda.

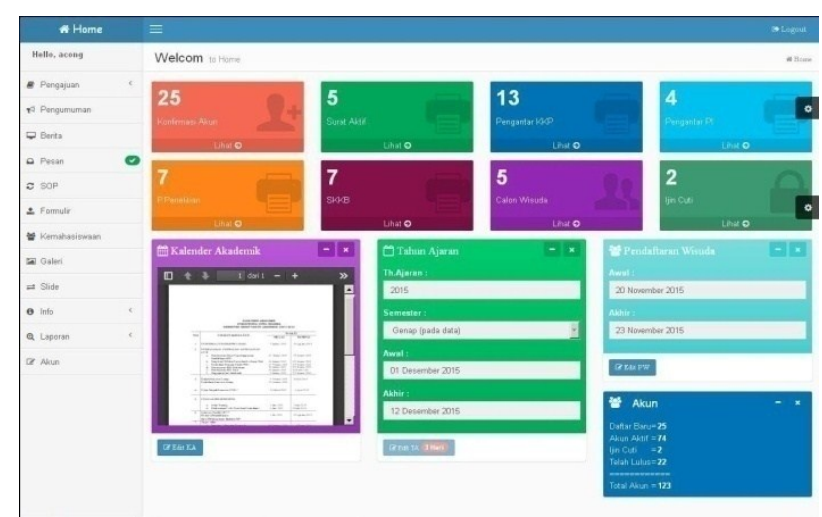

\section{Gambar 15. Halaman Home Staf BAAK}

6. Halaman Home Ketua BAAK

Gambar 16, merupakan halaman home untuk kepala BAAK, terdapat info jumlah pengajuan untuk mengawasi pekerjaan staf BAAK, fitur merubah kalender akademin, tahun ajaran yang berlangsung, dan pendaftaran wisuda.

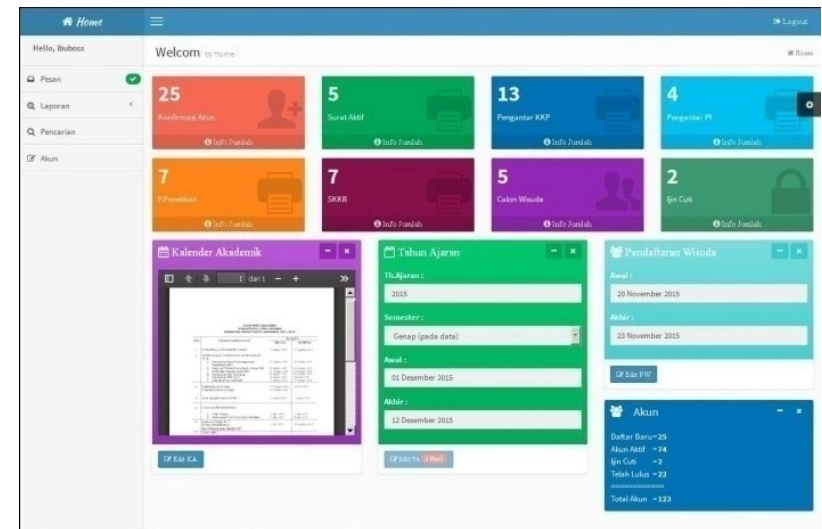

\section{Gambar 16. Halaman Home Ketua BAAK}

\section{Pengujian sistem}

Pengujian sistem menggunakan pengujian beta testin, dengan mengambil 30 orang responden untuk menilai halaman pengunjung dan mahasiswa, dari hasil kuesioner yang didapat akan dihitung penilainnya dengan rumus:

$$
\mathrm{Y}=\mathrm{P} / \mathrm{Q} * 100 \%
$$

Keterangan :

$\mathrm{Y}=$ Nilai Presentasi

$\mathrm{P}=$ Banyaknya jawaban responden tiap soal

$\mathrm{Q}=$ Jumlah responden

penilaian memakai 5 tingkat grade nilai dan bobot yang diberikan yaitu:

Tabel 5. Tabel Grade Nilai dan Bobot

\begin{tabular}{|l|c|c|}
\hline Jawaban & Bobot & Kode \\
\hline $\begin{array}{l}\text { Sangat tidak mudah, sangat tidak } \\
\text { bagus, sangat tidak bermanfaat, } \\
\text { sangat tidak cepat, sangat tidak } \\
\text { baik, sangat tidak membantu }\end{array}$ & 1 & Stb \\
\hline $\begin{array}{l}\text { Tidak mudah, tidak bagus, tidak } \\
\text { bermanfaat, tidak cepat, tidak baik, } \\
\text { tidak membantu }\end{array}$ & 2 & $\mathrm{~Tb}$ \\
\hline Biasa saja & 3 & $\mathrm{Bs}$ \\
\hline $\begin{array}{l}\text { Mudah, bagus, bermanfaat, cepat, } \\
\text { baik, membantu }\end{array}$ & 4 & $\mathrm{~B}$ \\
\hline $\begin{array}{l}\text { Sangat mudah, sangat bagus, } \\
\text { sangat bermanfaat, sangat cepat, } \\
\text { sangat baik, sangat membantu }\end{array}$ & 5 & $\mathrm{Sb}$ \\
\hline
\end{tabular}

Dari tabel sekor penilaian, maka mendapatkan nilai rata-rata dan presentase sebagi berikut:

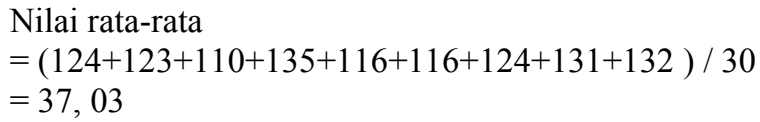

Persentase

$=37,03 / 45 * 100 \%$

$=82,29 \%$

Tabel 6. Tabel Skor Penilaian

\begin{tabular}{|c|c|c|c|c|c|c|}
\hline \multirow{2}{*}{$\begin{array}{c}\text { No } \\
\text { Soal }\end{array}$} & \multicolumn{5}{|c|}{ Jawaban dari 30 responden } & \multirow{2}{*}{$\begin{array}{c}\text { Bobot } \\
\text { Nilai }\end{array}$} \\
\cline { 2 - 6 } & Stb & Tb & Bs & B & Sb & \\
\hline 1 & $1 \times 0$ & $2 \times 0$ & $3 \times 4$ & $4 \times 18$ & $5 \times 8$ & 124 \\
\hline 2 & $1 \times 0$ & $2 \times 1$ & $3 \times 6$ & $4 \times 12$ & $5 \times 11$ & 123 \\
\hline 3 & $1 \times 0$ & $2 \times 2$ & $3 \times 8$ & $4 \times 18$ & $5 \times 2$ & 110 \\
\hline 4 & $1 \times 0$ & $2 \times 0$ & $3 \times 1$ & $4 \times 13$ & $5 \times 16$ & 135 \\
\hline 5 & $1 \times 2$ & $2 \times 1$ & $3 \times 2$ & $4 \times 19$ & $5 \times 6$ & 116 \\
\hline 6 & $1 \times 0$ & $2 \times 1$ & $3 \times 5$ & $4 \times 21$ & $5 \times 3$ & 116 \\
\hline 7 & $1 \times 0$ & $2 \times 0$ & $3 \times 5$ & $4 \times 16$ & $5 \times 9$ & 124 \\
\hline 8 & $1 \times 0$ & $2 \times 0$ & $3 \times 0$ & $4 \times 19$ & $5 \times 11$ & 131 \\
\hline 9 & $1 \times 0$ & $2 \times 1$ & $3 \times 0$ & $4 \times 15$ & $5 \times 14$ & 132 \\
\hline
\end{tabular}

Berdasarkan perolehan persentase nilai yang diberikan oleh 30 responden mengenai 9 keriteria website yang baik mendapatkan nilai sebesar $82,29 \%$, Maka sistem informasi administrasi akademik pada BAAK STMIK widya cipta dharma Samarinda berbasis web ini dapat diterima, karena hasil persentase yang didapat melebihi $50 \%$ dan dapat dikatakan termasuk website yang baik.

\section{KESIMPULAN}

Berdasarkan uraian dan hasil pembahasan maka penulis dapat mengambil kesimpulan sebagai berikut:

1. sistem informasi berbasis website yang dibuat akan mempermudah dalam menyampaikan informasi mengenai akademik, dan mengurangi pengunakan kertas untuk pengumuman.

2. website yang dibuat dapat mempermudah dalam pembuatan surat keperluan akademik karena data telah diisi oleh mahasiswa dan staf BAAK hanya mengecek dan mencetak surat 
3. BAAK memiliki histori pengajuan dan detail pengajuan yang dilakukan untuk pengecekan dan keperluan yang lain

4. BAAK memiliki grafik / penghitung pengajuan mahasiswa, sehingga mempermudah dalam pembuatan laporan

5. BAAK memiliki grafik untuk informasi mengenai lulusan dan calon wisuda yang mendaftar

6. BAAK memiliki informasi data diri mahasiswa dari akun mahasiswa

7. Mahasiswa yang sedang tidak dikampus namun memiliki pertanyaan seputar akademik dapat dengan mudah menanyakan ke pada staf BAAK melalui chat atau pesan

8. Mungurangi pertanyaan dasar tentang pengajuan / pembuatan surat akademik yang berulang karena informasi sudah disediakan disatu tempat

9. Orang tua mahasiswa atau pihak lain dapat bertanya mengenai akademik melalui halaman kontak dengan menggunakan fasilitas chat atau pesan

\section{SARAN}

Dari pembahasan dan kesimpulan maka penulis memberikan saran sebagai berikut:

1. Diharapkan untuk pengembangan sistem ini selanjut bisa menambahkan pengamanan sistem karena pengamanan sistem yang dibuat masih dirasa kurang.

2. Penambahan fitur edit pada pengajuan mahasiswa, untuk merubah atau membenarkan penulisan.

3. Membuat pengelompokan pengajuan untuk KKP, penulisan ilmiah, dan penelitian yang saat ini hanya sanggup mencetak satu persatu.

4. Memperbaiki tampilan halaman pengunjung yang dirasa masih kurang

5. Menambahkan fitur untuk merubah pengesahan surat yang saat ini masih belum ada

6. Menambah syarat memulai chat pada bagian kontak yang sat ini hanya mengisi nama untuk memulainya.

7. Menambahkan fitur lain untuk melengkapi dan mempermudah tugas BAAK yang lain.

\section{DAFTAR PUSTAKA}

Herman Suyanto Asep, 2007, Step By Step Web Designer Theory And Proctices, Yogyakarta: Andi.

Hidayat Rahmat, 2010, Cara Praktik Membangun Website Gratis, Jakarta: Elex Media.

Jogiyanto, H.M., 2008, Analisis \&Desain Sistem Informasi, Yogyakarta: Andi Offset.

Jogiyanto, H.M., 2009, Sistem Teknologi Informasi (Edisi Ketiga), Yogyakarta: Andi.

Kurniawan Dedik dan Creativity Java, 2010, 145 freeware untuk berbagai kebutuhan, Jakarta : Elex Media Komputindo.
Madcoms, 2008, Aplikasi program PHP dan MYSQL Untuk Membuat Web site Interaktif, Yogyakarta: Andi.

Mcleod, Raymond, 2008, Sistem Informasi Manajemen (Edisi 10), Jakarta: Salemba Empat.

Mulyanto, Agus, 2009, Sistem Informasi Konsep dan Aplikasi, Yogyakarta: Pustaka Pelajar.

Nugroho, B., 2008, Latihan Membuat Aplikasi Web PHP dan MySQL dengan Dreamweaver $M X$, Jakarta : Elex Media Komputindo.

Prasetio, adhi, 2012, Buku Pintar Pemrograman Web, Jakarta: mediakita.

Pratama, I Putu Agus Eka, 2014, Sistem Informasi dan Implementasinya, Bandung: Informatika.

Pressman, Roger S., 2007, Rekayasa Perangkat Lunak (Buku Satu), Yogyakarta: Andi.

Shalahuddin, M. \& AS Rosa, 2010, Java di Web, Bandung: Informatika.

Simarmata, Janner. 2010. Rekayasa Perangkat Lunak, Yogyakarta: Andi.

Sukmana, Ikmal Ratmatillah, 2011, Pembelajaran Bahasa Arab Tingkat Dasar Berbasis Web Dengan Metode Interactive Learning, Bandung : UNIKOM.

Swastika, Windra, 2006, PHP 5dan MySQL 4 (proyek membuat blog), Jakarta: Dian Rakyat.

Wicaksono, Yogi \& SmitDev Community, 2008, Membangun Bisnis Online dengan Mambo, Jakarta: Elex Media Komputindo.

Wiswakarma, K., 2010, Panduan Lengkap Menguasai Pemrograman CSS, Yogyakarta: Lokomedia.

Yuhefizar, 2012, Mudah Membangun Web Profil Multibahasa. Jakarta: Elex Media. 